MaPan : Jurnal Matematika dan Pembelajaran

p-ISSN: 2354-6883 ; e-ISSN: 2581-172X

Volume 4, Nomor 2, Desember 2016

\title{
PENGARUH PENGETAHUAN METAKOGNISI DAN GAYA BELAJAR VISUAL TERHADAP KEMAMPUAN PEMECAHAN MASALAH MATEMATIKA SISWA KELAS IX SMP NEGERI 2 BAROMBONG KABUPATEN GOWA
}

\author{
Syahrina Syam 1), Ulfiani Rahman'2), Nursalam ${ }^{3)}$ \\ 1,2,3Fakultas Tarbiyah dan Keguruan UIN Alauddin Makassar \\ 1,2,3Kampus II: Jalan H. M. Yasin Limpo Nomor 36 Samata-Gowa \\ E-mail: syahrina.syam@yahoo.com ${ }^{1)}$, ulfiani.rahman@uin-alauddin.ac.id ${ }^{2}$, \\ nursalam_ftk@uin-alauddin.ac.id ${ }^{3}$ )
}

\begin{abstract}
Abstrak
Penelitian ini bertujuan untuk mengetahui apakah terdapat pengaruh pengetahuan metakognisi dan gaya belajar visual terhadap kemampuan pemecahan masalah matematika siswa kelas IX SMPN 2 Barombong. Jenis penelitian ini adalah penelitian kuantitatif dengan pendekatan korelasional. Teknik analisis yang digunakan adalah analisis statistik deskriptif dan analisis statistik inferensial dengan teknik analisis Regresi Linier Berganda. Penelitian menunjukkan bahwa ada pengaruh pengetahuan metakognisi dan gaya belajar visual terhadap kemampuan pemecahan masalah matematika siswa kelas IX SMPN 2 Barombong. Berdasarkan hasil analisis data menggunakan statistik deskriptif untuk pengetahuan metakognisi diperoleh nilai rata-rata 82,52 berada pada kategori sedang dari 93 sampel diperoleh nilai terendah 61, nilai tertinggi 105 dan untuk gaya belajar visual diperoleh nilai rata-rata 55,22 berada pada kategori sedang dari 93 sampel diperoleh nilai terendah 46, nilai tertinggi 65 , serta untuk tingkat pemecahan masalah matematika diperoleh nilai rata-rata 71,18 berada pada kategori sedang dari 93 sampel diperoleh nilai terendah 34, nilai tertinggi 100. Adapun hasil analisis statistik inferensial (Regresi Linear Berganda) diperoleh $F_{\text {hitung }}>F_{\text {tabel }}(3,645>3,10)$. Dengan demikian dapat disimpulkan bahwa pengetahuan metakognisi dan gaya belajar visual berpengaruh terhadap kemampuan pemecahan masalah matematika siswa.
\end{abstract}

Kata Kunci: Metakognisi, Gaya Belajar Visual, Pemecahan Masalah

$\mathrm{P}$ endidikan sering diartikan sebagai usaha manusia untuk membina kepribadiannya sesuai dengan nilai-nilai di dalam masyarakat dan kebudayaan. Dalam perkembangannya, istilah pendidikan atau pedagogik berarti bimbingan atau pertolongan yang diberikan dengan sengaja oleh orang dewasa agar ia menjadi dewasa. Menurut Undang-Undang Republik Indonesia Nomor 20 tahun 2003 pendidikan adalah usaha sadar dan terencana untuk mewujudkan suasana belajar dan proses pembelajaran agar peserta didik secara aktif mengembangkan potensi dirinya untuk memiliki 
kekuatan spiritual keagamaan, pengendalian diri, kepribadian, kecerdasan, akhlak mulia, serta keterampilan yang diperlukan dirinya, masyarakat, bangsa dan negara. Namun, pendidikan sekolah merupakan bagian yang perlu diperhatikan oleh pemerintah dan para tenaga pendidik untuk mengahasilkan sumber daya manusia yang berkualitas.

Pendidikan sekolah yang dimaksud di sini adalah pendidikan yang diperoleh seseorang di sekolah secara teratur, sistematis, bertingkat, dan dengan mengikuti syarat-syarat yang jelas dan ketat (mulai dari taman kanakkanak sampai perguruan tinggi). Selain itu dapat dikatakan bahwa pendidikan di sekolah merupakan bagian dari pendidikan dalam keluarga, yang sekaligus juga merupakan lanjutan dari pendidikan keluarga.

Pendidikan di sekolah peserta didik wajib untuk belajar, maka ada pelajaran atau mata pelajaran yang telah ditentukan untuk dipelajari oleh peserta didik. Salah satu mata pelajaran yang ada pada pendidikan di sekolah ialah pelajaran matematika.

Matematika adalah suatu cara untuk menemukan jawaban terhadap masalah yang dihadapi manusia, suatu cara menggunakan informasi, menggunakan pengetahuan tentang bentuk dan ukuran, menggunakan pengetahuan tentang menghitung, dan yang paling penting adalah memikirkan dalam diri manusia itu sendiri dalam melihat dan menggunakan hubungan-hubungan. Karakteristik matematika terdiri atas, matematika memiliki obyek kajian yang abstrak, bertumpu pada kesepakatan, berpola pikir deduktif, memiliki simbol yang kosong dari arti, memperhatikan semesta pembicaraan, dan konsisten dalam sistemnya. Matematika merupakan bidang studi yang dipelajari oleh semua siswa dari SD hingga SLTA dan bahkan juga di perguruan tinggi. Ada banyak alasan tentang perlunya siswa belajar matematika. Kesadaran akan proses berpikirnya ini yang disebut sebagai metakognisi.

Metakognisi sebagai suatu bentuk kognisi, atau proses berpikir dua tingkat atau lebih yang melibatkan pengendalian terhadap aktivitas kognitif. Olehnya itu, metakognisi dapat dikatakan sebagai berpikir seseorang tentang berpikirnya sendiri atau kognisi seseorang tentang kognisinya sendiri. Selain itu, metakognisi melibatkan pengetahuan dan kesadaran seseorang tentang aktivitas kognitifnya sendiri atau segala sesuatu yang berhubungan dengan aktivitas kognitifnya. Dengan demikian, aktivitas kognitif seseorang seperti perencanaan, monitoring, dan mengevaluasi penyelesaian suatu tugas tertentu merupakan metakognisi secara alami. Metakognisi atau "berpikir tentang 
berpikir", adalah pengetahuan dan pemahaman yang kita miliki tentang proses-proses kognitif kita sendiri dan kemampuan yang kita miliki untuk mengkaji pemikiran kita dan memantau apa yang terjadi.

Gaya belajar juga memengaruhi bagaimana cara mereka dapat memecahkan suatu permasalahan terutama dalam kehidupan sehari-hari. Ada beberapa jenis gaya belajar siswa, salah satunya adalah gaya belajar visual. Gaya belajar visual (penglihatan), yaitu gaya belajar dimana seseorang belajar yang paling baik ketika mereka melihat gambar yang mereka pelajari, sebagian kecil mereka berorientasi pada teks tercetak dan dapat belajar melalui membaca.

Inteligensi visual meliputi kumpulan kemampuan yang saling terkait, termasuk perbedaan visual, pengenalan visual, proyeksi, gambaran mental, pertimbangan ruang, manipulasi gambar dalam atau gambaran eksternal, setiap atau semua yang dapat diekspresikan.

Berdasarkan hasil observasi pembelajaran matematika pada bulan Juli 2014 yang berlangsung di kelas IX SMP Negeri 2 Barombong Kabupaten Gowa, peneliti menemukan bahwa dalam proses pembelajaran terdapat, beberapa siswa yang kurang memperhatikan apa yang disampaikan oleh gurunya, siswa kurang aktif ketika pelajaran matematika, sikap siswa yang terkesan malas-malasan dalam menerima pelajaran matematika, siswa berbicara dengan temannya ketika pelajaran matematika berlangsung, siswa belum dapat memecahkan masalah matematika jika tidak sama persis dengan contoh soal yang diberikan oleh gurunya.

Berdasarkan uraian tersebut di atas penulis tertarik melakukan penelitian dengan judul "Pengaruh Pengetahuan Metakognisi dan Gaya Belajar Visual terhadap Pemecahan Masalah Matematika Siswa Kelas IX SMP Negeri 2 Barombong Kab. Gowa."

\section{METAKOGNISI}

Metakognisi adalah kognisi tentang kognisi, atau "mengetahui tentang mengetahui". Metakognisi atau "berpikir tentang berpikir" adalah pengetahuan dan pemahaman yang dimiliki tentang proses-proses kognitif sendiri dan kemampuan yang dimiliki untuk mengkaji pemikiran dan memantau apa yang terjadi. Tujuan penting mengajarkan siswa cara berpikir adalah meningkatkan kesadaran mereka akan pemikiran mereka sendiri dan mengembangkan kemampuan metakognitif dan kemampuan memantau dan mengatur pembelajaran mereka sendiri. 
Keterampilan metakognitif telah diajarkan kepada murid untuk membantu mereka memecahkan soal matematika. Selama pelajaran matematika, guru membimbing anak yang kurang pandai untuk belajar mengetahui kapan mereka tidak tahu makna dari satu kata, tidak semua informasi yang diperlukan untuk memecahkan problem, tidak tahu cara membagi problem menjadi langkah-langkah spesifik, atau tidak tahu cara melakukan perhitungan. Setelah memberi pelajaran ini, murid yang diberi training metakognitif tersebut diharapkan akan mendapatkan nilai matematika yang lebih baik dan mempunyai sikap yang lebih baik terhadap matematika.

Siswa-siswa yang menggunakan metakognitifnya dengan baik akan menjadi pemikir yang kritis, problem solver yang baik, serta pengambil keputusan yang baik dari pada mereka yang tidak menggunakan metakognisinya. Di samping itu guru dapat meningkatkan penggunaan strategi metakognitif dalam membahas suatu konsep yang baru dengan mengingatkan kembali apa yang sudah diketahui siswa.

Metakognitif membantu anak-anak untuk melakukan banyak tugas akademik yang lebih efektif. Keterampilan metakognitif juga telah diajarkan kepada siswa untuk membantu mereka memecahkan masalah. Dalam satu studi, dimana masing-masing 30 pelajaran harian yang melibatkan soal cerita matematika, guru memandu siswa dengan pencapaian rendah dalam belajar untuk mengenali ketika mereka tidak tahu arti dari sebuah kata, tidak memiliki semua informasi yang diperlukan untuk memecahkan masalah, tidak tahu bagaimana untuk membagi masalah ke dalam langkah-langkah spesifik, atau tidak tahu melaksanakan perhitungan. Setelah 30 pelajaran harian, mahasiswa yang diberi pelatihan metakognitif ini memiliki prestasi belajar matematika yang lebih baik dan sikap yang lebih baik terhadap matematika.

Aspek penting dari metakognisi adalah pemantauan seberapa baik seseorang tampil pada tugas. Hal ini mungkin melibatkan kesadaran bahwa seseorang belum cukup belajar untuk sebuah tes atau perlu membaca lagi bagian tertentu dari sebuah bab untuk memahami dengan lebih baik.

Dalam proses pembelajaran pengetahuan metakognisi siswa memiliki peranan penting. Pengetahuan metakognisi yang baik dapat mendorong siswa menjadi lebih memahami proses berpikirnya sendiri sehingga siswa lebih mandiri dalam belajar dan dapat mengtahui kelemahan dan kelebihan yang dimilikinya. 
Dari beberapa definisi di atas dapat disimpulkan bahwa pengetahuan metakognisi merupakan pengetahuan seseorang mengenai proses berpikirnya sendiri dalam memahami dan mengkaji apa yang sedang terjadi. Olehnya itu, seseorang dapat secara mandiri menyelesaikan suatu persoalan atau permasalahan.

\section{GAYA BELAJAR}

Gaya belajar merupakan sebuah pendekatan yang menjelaskan mengenai bagaimana individu belajar atau cara yang ditempuh oleh masing-masing orang untuk berkonsentrasi pada proses, dan menguasai informasi yang sulit dan baru melalui persepsi yang berbeda. Gaya belajar bersifat individual bagi setiap orang, dan untuk membedakan orang yang satu dengan orang yang lain. Dengan demikian, secara umum gaya belajar diasumsikan mengacu pada kepribadian-kepribadian, kepercayaan-kepercayaan, pilihan-pilihan, dan perilaku-prilaku yang digunakan oleh individu untuk membantu dalam belajar mereka dalam suatu situasi yang telah dikondisikan.

Gaya belajar visual (penglihatan), yaitu gaya belajar dimana seseorang belajar yang paling baik ketika mereka melihat gambar yang mereka pelajari, sebagian kecil mereka berorientasi pada teks tercetak dan dapat belajar melalui membaca. Anak yang memiliki gaya belajar visual lebih cenderung pada kecerdasan visual bagus/lebih dominan dibandingkan kecerdasan yang lainnya.

Dengan demikian, dapat disimpulkan bahwa gaya belajar visual adalah cara belajar siswa yang lebih didominasi oleh penglihatan dalam proses pembelajaran. Siswa dengan gaya belajar visual lebih senang melihat gambar daripada harus mendengarkan penjelasan dari gurunya.

\section{PEMECAHAN MASALAH MATEMATIKA}

Di dalam proses belajar mengajar matematika di sekolah, pertanyaan yang diberikan kepada siswa biasanya disebut dengan soal. Soal yang diberikan kepada siswa dapat dibedakan menjadi dua macam yaitu: (1) soal berupa latihan yang dimaksudkan melatih siswa terampil menerapkan pengalaman belajar matematika yang baru diperolehnya, (2) soal berupa masalah yang dimaksudkan mengembangkan kemampuan siswa menerapkan pengalaman belajar matematika yang lampau pada situasi lain.

Apabila dicermati pengertian masalah yang dikemukakan di atas, maka dapat dinyatakan bahwa masalah itu sifatnya subjektif dan tergantung dari 
waktu. Artinya, suatu masalah bagi seseorang belum tentu merupakan masalah bagi orang lain. Demikian pula suatu masalah bagi seseorang pada saat ini, namun tidak lagi merupakan masalah pada saat yang lain.

Proses berpikir dalam pemecahan masalah merupakan hal penting yang perlu mendapat perhatian para pendidik terutama untuk membantu siswa agar dapat mengembangkan kemampuannya memecahkan masalah. Tujuan utama mengajarkan pemecahan masalah dalam matematika adalah tidak hanya untuk melengkapi siswa dengan sekumpulan keterampilan atau proses, tetapi lebih kepada memungkinkan siswa berpikir tentang apa yang dipikirkannya.

Pada dasarnya tidak terdapat langkah-langkah penyelesaian masalah yang baku. Banyaknya langkah yang perlu ditempuh di dalam menyelesaikan suatu masalah, sangat tergantung dari tingkat kesukaran dan kemampuan yang dimiliki oleh orang yang menyelesaikan masalah. Namun demikian, terdapat banyak teknik atau strategi penyelesaian masalah yang dikemukakan para ahli dapat dijadikan sebagai kerangka acuan.

Untuk menyelesaikan masalah pada soal matematika diperlukan langkah-langkah sebagai berikut:

a. Merumuskan permasalahan dengan jelas.

b. Menyatakan kembali persoalannya dalam bentuk yang dapat diselesaikan.

c. Menyusun hipotesis (sementara) dan strategi pemecahannya.

d. Melaksanakan prosedur pemecahan.

e. Melakukan evaluasi terhadap penyelesaian.

Dalam penelitian ini diadakan penilaian untuk mengetahui kemampuan pemecahan masalah matematika siswa. Penilaian ini dapat dilakukan setelah siswa menyelesaikan suatu persoalan atau masalah dalam bentuk soal yang telah diberikan oleh guru dengan memperhatikan empat tahapan pemecahan masalah menurut George Polya yaitu pemahaman soal, pemikiran suatu rencana, pelaksanaan rencana, dan peninjauan kembali.

\section{METODE PENELITIAN}

Penelitian ini merupakan penelitian kuantitatif dengan pendekatan korelasional. Penelitian ini dilakukan di SMP Negeri 2 Barombong, Kecamatan Barombong, Kabupaten Gowa. Populasi dalam penelitian ini adalah seluruh siswa kelas IX SMP Negeri 2 Barombong, Kecamatan Barombong, Kabupaten Gowa yang terdiri atas 7 kelas dengan jumlah siswa 265 orang. Sampel dalam penelitian ini adalah 35\% dari populasi yakni sebanyak 93 orang. 
Instrumen yang digunakan dalam penelitian ini adalah skala pengetahuan metakognisi, gaya belajar visual dan tes pemecahan masalah matematika. Teknik analisis yang digunakan adalah analisis statistik deskriptif dan analisis statistik inferensial dengan teknik analisis Regresi Linier Berganda. Analisis satistik deskriptif digunakan untuk mendriskipsikan atau memberi gambaran terhadap objek yang diteliti melalui data sampel atau populasi sebagaimana adanya, tanpa melakukan analisis dan membuat kesimpulan yang berlaku untuk umum seperti rata-rata, median, modus, standar deviasi dan presentase. Uji prasyarat dalam penelitian ini adalah uji normalitas, uji linearitas selanjutnya pengujian hipotesis.

\section{HASIL PENELITIAN DAN PEMBAHASAN}

\section{Gambaran Pengetahuan Metakognisi Siswa Kelas IX SMP Negeri 2 Barombong Kabupaten Gowa}

Berikut ini adalah tabel hasil analisis deskriptif data pengetahuan metakognisi siswa kelas IX di SMP Negeri 2 Barombong Kabupaten Gowa.

Tabel 1. Descriptive Statistics Pengetahuan Metakognisi Siswa Kelas IX di SMP Negeri 2 Barombong Kabupaten Gowa

\begin{tabular}{cc}
\hline Statistik & Skor Statistic \\
\hline Sampel & 93 \\
skor terendah & 61,00 \\
skor tertinggi & 105,00 \\
Rata-rata & 82,52 \\
Standar Deviasi & 8,96 \\
\hline
\end{tabular}

Dari tabel 1 menunjukkan bahwa pengetahuan metakognisi siswa pada siswa kelas IX SMP Negeri 2 Barombong Kabupaten Gowa yang didapatkan melalui instrumen skala menunjukkan bahwa skor tertinggi 105, skor terendah adalah 61 . Skor rata-rata yang diperoleh adalah 82,52 . Standar deviasi sebesar 8,96 .

Dari data tabel di atas selanjutnya menyusun tabel distribusi frekuensi dan perhitungan data pengetahuan metakognisi siswa kelas IX SMP Negeri 2 Barombong Kabupaten Gowa dan akan disajikan dalam bentuk tabel berikut: 
Tabel 2. Distribusi Frekuensi Data Pengetahuan Metakognisi Siswa Kelas IX SMP Negeri 2 Barombong Kabupaten Gowa

\begin{tabular}{|c|c|c|c|c|}
\hline Batas kategori & Interval & Frekuensi & Persentase & Ket. \\
\hline$x<(\mu-1,0 \sigma)$ & $x<74$ & 17 & $18 \%$ & Rendah \\
\hline$(\mu-1,0 \sigma) \leq x<(\mu+1,0 \sigma)$ & $74 \leq x<91$ & 58 & $63 \%$ & Sedang \\
\hline$(\mu+1,0 \sigma) \leq x$ & $91 \leq x$ & 18 & $19 \%$ & Tinggi \\
\hline Total & & 93 & $100 \%$ & \\
\hline
\end{tabular}

Berdasarkan tabel distribusi frekuensi di atas, diperoleh bahwa terdapat 17 siswa atau 18\% memiliki pengetahuan metakognisi yang rendah, 58 siswa atau 63\% memiliki pengetahuan metakognisi yang sedang, dan 18 siswa atau 19\% memiliki pengetahuan metakognisi tinggi. Dengan demikian dapat disimpulkan bahwa skor pengetahuan metakognisi pada seluruh subjek penelitian ini termasuk kategori sedang.

\section{Gambaran Gaya Belajar Visual Siswa Kelas IX SMP Negeri 2 Barombong Kabupaten Gowa}

Berdasarkan skala gaya belajar visual dengan jumlah 20 butir pernyataan yang telah diberikan kepada siswa di kelas IX SMP Negeri 2 Barombong Kabupaten Gowa didapatkan hasil sebagai berikut:

Tabel 3. Descriptive Statistics Gaya Belajar Visual Siswa Kelas IX SMP Negeri 2 Barombong Kabupaten Gowa

\begin{tabular}{cc}
\hline Statistik & Skor statistik \\
\hline Sampel & 93 \\
skor terendah & 46,00 \\
skor tertinggi & 65,00 \\
Rata-rata & 55,22 \\
Standar Deviasi & 4,11 \\
\hline
\end{tabular}

Berdasarkan tabel di atas, maka dapat diketahui bahwa skor maksimum yang diperoleh peserta didik adalah 65, sedangkan skor minimum adalah 46 dengan rata-rata sebesar 55,22. Standar deviasi sebesar 4,11. 


\section{Gambaran Kemampuan Pemecahan Masalah Matematika Siswa Kelas IX SMP Negeri 2 Barombong Kabupaten Gowa}

Berdasarkan tes pemecahan masalah matematika yang diberikan peserta didik pada kelas IX SMP Negeri 2 Barombong Kabupaten Gowa yang berjumlah 93 siswa didapatkan hasil sebagai berikut:

Tabel 4. Descriptive Statistics Kemampuan Pemecahan Masalah Matematika Siswa Kelas IX SMP Negeri 2 Barombong Kabupaten Gowa

\begin{tabular}{cc}
\hline Statistik & Skor statistic \\
\hline Sampel & 93 \\
skor terendah & 34,00 \\
skor tertinggi & 100,00 \\
Rata-rata & 71,18 \\
Standar Deviasi & 12,80 \\
\hline
\end{tabular}

Dari tabel diperoleh hasil bahwa kemampuan pemecahan masalah matematika pada siswa kelas IX SMP Negeri 2 Barombong Kabupaten Gowa yang didapatkan dari hasil tes pemecahan masalah matematika yang berbentuk esai menunjukkan bahwa skor tertinggi 100, skor terendah adalah 34 dan rata-rata yang diperoleh adalah 71,18. Standar deviasi sebesar 12,80.

Selanjutnya menyusun tabel distribusi frekuensi dan perhitungan data tingkat pemecahan masalah matematika siswa kelas IX SMP Negeri 2 Barombong dimasukkan dalam kategori rendah, sedang, dan tinggi sebagai berikut:

Tabel 4. Distribusi Frekuensi Data Kemampuan Pemecahan Masalah Matematika Siswa Kelas IX SMP Negeri 2 Barombong Kabupaten Gowa

\begin{tabular}{|c|c|c|c|c|}
\hline Batas kategori & Interval & Frekuensi & Presentase & Ket. \\
\hline$X<(\mu-1,0 \sigma)$ & $X<58$ & 12 & $13 \%$ & Rendah \\
\hline$(\mu-1,0 \sigma) \leq \mathrm{X}<(\mu+1,0 \sigma)$ & $58 \leq X<84$ & 66 & $71 \%$ & Sedang \\
\hline$(\mu+1,0 \sigma) \leq X$ & $84 \leq X$ & 15 & $16 \%$ & Tinggi \\
\hline Total & & 93 & $100 \%$ & \\
\hline
\end{tabular}

Berdasarkan tabel di atas, data menunjukkan bahwa kecenderungan kemampuan pemecahan masalah matematika siswa kelas IX SMP Negeri 2 Barombong berpusat pada kategori sedang yaitu 71\% atau sebanyak 66 siswa. Dengan demikian dapat disimpulkan bahwa skor kemampuan pemecahan 
masalah matematika pada seluruh subjek penelitian ini termasuk kategori sedang.

\section{Pengaruh Pengetahuan Metakognisi dan Gaya Belajar Visual Terhadap Kemampuan Pemecahan Masalah Matematika Siswa Kelas IX SMP Negeri 2 Barombong Kabupaten Gowa}

Pada bagian ini akan dibahas tentang rumusan masalah yang keempat menggunakan statistik inferensial pada bagian ini akan diketahui ada tidaknya pengaruh terhadap kemampuan pemecahan masalah matematika.

Pengujian normalitas pertama dilakukan pada pengetahuan metakognisi. Taraf signifinikan yang ditetapkan adalah $\propto=0,05$. Berdasarkan hasil pengolahan dengan SPSS 16 maka diperoleh sig. adalah 0,664 dengan demikian dapat disimpulkan bahwa data pengetahuan metakognisi berdistribusi normal karena nilai sig. lebih besar dari $\propto$ atau $(0,664>0,05)$. Pengujian normalitas kedua dilakukan pada gaya belajar visual. Dari hasil SPSS diperoleh sig. sebesar 0,281 sedangkan taraf signifikan yang ditetapkan adalah $\propto=0,05$. Karena sig. $=0,281>\propto=0,05$ maka dapat disimpulkan bahwa gaya belajar visual berdistribusi normal. Pengujian normalitas ketiga dilakukan pada kemampuan pemecahan masalah matematika. Berdasarkan hasil output SPSS, dapat dilihat bahwa sign sebesar 0,51 dan taraf signifikasni yang ditetapkan adalah $\propto=0,05$ dengan demikian maka dapat dikatakan bahwa data kemampuan pemecahan masalah matematika siswa kelas IX pada SMP Negeri 2 Barombong berditribusi normal karena (sig. $=0,516>\propto=0,05$ ).

Hasil uji linieritas pengetahuan metakognisi terhadap kemampuan pemecahan masalah matematika diperoleh hasil sig. 0,031 $<\alpha$ berarti data pengetahuan metakognisi linear.Sedangkan uji linieritas gaya belajar visual terhadap kemampuan pemecahan masalah matematika diperoleh hasil sig. $0,044<\alpha$ sehingga data gaya belajar visual linear.

Pada analisis regresi linier berganda ini digunakan untuk mengetahui pengaruh pengetahuan metakognisi dan gaya belajar visual terhadap kemampuan pemecahan masalah matematika siswa kelas IX SMP Negeri 2 Barombong Kabupaten Gowa.

Rumus analisis regresi linier berganda dengan menggunakan SPSS versi 16 sebagai berikut:

$$
\mathrm{Y}=31,86+0,181 \mathrm{X}_{1}+0,441 \mathrm{X}_{2}
$$

$\mathrm{Y}$ adalah kemampuan pemecahan masalah matematika, $\mathrm{X}_{1}$ adalah pengetahuan metakognisi, dan $\mathrm{X}_{2}$ adalah gaya belajar visual. Dari persamaan 
di atas, dapat di analisis beberapa hal antara lain:

Kemampuan pemecahan masalah matematika, jika tanpa adanya pengetahuan metakognisi dan gaya belajar visual $\left(X_{1}=0\right.$ dan $\left.X_{2}=0\right)$, maka kemampuan pemecahan masalah matematika hanya $31,86=31$. Sedangkan bila masing-masing siswa jawabannya bertambah 1 poin untuk jawaban pengetahuan metakognisi dan gaya belajar visual $\left(X_{1}=93\right.$ dan $\left.X_{2}=93\right)$, maka diperkirakan kemampuan pemecahan masalah matematika akan naik menjadi 89.

Berdasarkan tabel diperoleh angka $\mathrm{R}^{2}$ ( $\mathrm{R}$ Square) sebesar 0,560 atau (56\%). Hal ini menunjukkan bahwa persentase sumbangan pengetahuan metakognisi dan gaya belajar visual terhadap kemampuan pemecahan masalah matematika sebesar 56\% sedangkan sisanya sebesar $44 \%$ dipengaruhi atau dijelaskan oleh variabel lain yang tidak dimasukkan dalam model penelitian ini.

Adjusted $R$ Square adalah nilai $R$ Square yang telah disesuaikan, nilai ini selalu lebih kecil dari $\mathrm{R}$ Square dan angka ini bisa memiliki harga negatif. Untuk regresi dengan lebih dari dua variabel bebas digunakan Adjusted $\mathrm{R}^{2}$ sebagai koefisien determinasi. Adapun nilainya sebesar 0,035. Standard Error of the Estimate adalah ukuran kesalahan prediksi, nilainya sebesar 12,581. Artinya kesalahan yang dapat terjadi dalam memprediksi variabel Y (kemampuan pemecahan masalah matematika) sebesar 12,581.

Hasil penelitian menunjukkan bahwa pengetahuan metakognisi dan gaya belajar visual berpengaruh positif dan signifikan terhadap kemampuan pemecahan masalah matematika siswa kelas IX SMP Negeri 2 Barombong Kabupaten Gowa. Hasil yang diperoleh sesuai dengan penelitian sebelumnya yang dilakukan secara terpisah. Hasil penelitian ini menunjukkan bahwa secara bersama-sama pengetahuan metakognisi dan gaya belajar visual berpengaruh secara signifikan terhadap kemampuan pemecahan masalah matematika siswa kelas IX SMP Negeri 2 Barombong Kabupaten Gowa. Koefisien determinasi sebesar 56\% menunjukkan bahwa 56\% pemecahan masalah matematika siswa dapat dijelaskan oleh pengetahuan metakognisi dan gaya belajar visual siswa. Sehubungan dengan hal tersebut, maka dalam penelitian ini dapat dikatakan bahwa pengetahuan metakognisi dan gaya belajar visual siswa memiliki jumlah pengaruh yang besar terhadap kemampuan pemecahan masalah matematika siswa kelas IX SMP Negeri 2 Barombong Kabupaten Gowa. Adapun faktor lain yang juga berpengaruh terhadap kemampuan pemecahan masalah matematika siswa, seperti faktor 
pengetahuan matematika dan keterampilan siswa dalam bernalar yang memegang peranan penting dalam pengaruhnya terhadap pemecahan masalah matematika.

Namun, hasil penelitian ini menunjukkan bahwa siswa kelas IX SMP Negeri 2 Barombong masih memiliki pengetahuan metakognisi yang sedang. Hal ini disebabkan oleh faktor instrinsik (seperti cita-cita dan aspirasi peserta didik, kemampuan peserta didik, serta kondisi peserta didik) dan faktor ekstrinsik (seperti kondisi lingkungan peserta didik dan upaya guru dalam membelajarkan peserta didik). Hasil penelitian ini menunjukkan bahwa siswa kelas IX SMP Negeri 2 Barombong masih memiliki gaya belajar visual yang sedang. Hal ini disebabkan oleh faktor eksternal (seperti faktor lingkungan), faktor psikologis, dan faktor internal (seperti adanya gangguan perkembangan otak).

Berdasarkan hasil pembahasan di atas, maka pada penelitian ini dapat disimpulkan bahwa pengetahuan metakognisi dan gaya belajar visual siswa secara bersama-sama memiliki pengaruh yang signifikan dan positif terhadap kemampuan pemecahan masalah matematika siswa kelas IX SMP Negeri 2 Barombong Kabupaten Gowa. Hal ini menunjukkan bahwa pengetahuan metakognisi dan gaya belajar visual siswa memiliki pengaruh yang cukup berarti terhadap kemampuan pemecahan masalah matematika siswa. Apabila pengetahuan metakognisi dan gaya belajar visual siswa meningkat, maka kemampuan pemecahan masalah matematika siswa akan meningkat pula. Dengan demikian terdapat hubungan antara pengetahuan metakognisi dan gaya belajar visual siswa di sekolah dengan kemampuan pemecahan masalah matematika yang tidak boleh diabaikan.

\section{SIMPULAN}

Berdasarkan dari uraian analisis statistik dan pembahasan tersebut, maka penulis dapat menarik kesimpulan sebagai berikut:

a. Gambaran pengetahuan metakognisi siswa kelas IX SMP Negeri 2 Barombong Kabupaten Gowa berada pada kategori rendah sebanyak 18\%, kategori sedang sebanyak 63\%, dan pada kategori tinggi sebanyak 19\% sehingga secara umum pengetahuan metakognisi berada pada kategori sedang.

b. Gambaran gaya belajar visual siswa kelas IX SMP Negeri 2 Barombong Kabupaten Gowa berada pada kategori rendah sebanyak 13\%, kategori 
sedang $64 \%$ dan pada kategori tinggi sebanyak 23\% sehingga secara umum gaya belajar visual berada pada kategori sedang.

c. Gambaran kemampuan pemecahan masalah matematika siswa kelas IX SMP Negeri 2 Barombong Kabupaten Gowa berada pada kategori rendah sebanyak $13 \%$, kategori sedang $71 \%$ dan pada kategori tinggi sebanyak $16 \%$ sehingga secara umum tingkat pemecahan masalah matematika berada pada kategori sedang.

d. Berdasarkan hasil analisis statistik inferensial pengetahuan metakognisi dan gaya belajar visual berpengaruh terhadap kemampuan pemecahan masalah matematika siswa kelas IX SMP Negeri 2 Barombong Kabupaten Gowa. Sumbangsi pengaruh variabel pengetahuan metakognisi dan gaya belajar visual $56 \%$ sedangkan selebihnya $44 \%$ dipengaruhi oleh variabel lain yang tidak dimasukkan dalam penelitian ini.

\section{DAFTAR PUSTAKA}

Abdurrahman, M. (2003). Pendidikan bagi anak berkesulitan belajar; Jakarta: Rineka Cipta.

Arends, R. I. (2013). Learning to teach; Jakarta: Salemba Humanika.

Arikunto, S., \& Rosdakarya. (2002). Prosedur penelitian suatu pendekatan praktek. Cet I, Jakarta: Rineka Cipta.

Arikunto, S. (2005). Prosedur penelitian suatu pendekatan praktik. Cet XIV; Jakarta: Raja Drafindo Persada.

Azwar, S. (2013). Penyusunan Skala Psikologi; Yogyakarta: Pustaka Pelajar.

Campbel, L., dkk. (2006). Metode pembelajaran berbasis multiple intelligences ; Depok: Intuisi Press.

Departemen Agama R.I. (2008). Al-Quran dan terjemahnya; Bandung; Diponegoro.

Ellis, O. J. (2009). Psikologi pendidikan membantu siswa tumbuh dan berkembang (Edisi keenam); Jakarta: Erlangga.

Emzir. (2013). Metode penelitian pendidikan (kuantitatif dan kualitatif); Jakarta: PT. Raja Grafindo Persada. 
Halim, A. (2012). Pengaruh strategi pembelajaran dan gaya belajar terhadap hasil belajar fisika siswa SMPN 2 Secanggang Kabupaten Langkat; Jurnal Tabularasa PPS Unimed.

Hartini. (2008). Analisis kesalahan siswa menyelesaikan soal cerita pada kompetensi dasar menemukan sifat dan menghitung besar-besaran segi empat siswa kelas VII Semester II SMP IT Nur Hidayah Surakarta Tahun Pelajaran 2006/2007; Tesis.

Hudojo, H. (2005). Pengembangan kurikulum dan pembelajaran matematika; Malang: Universitas Negeri Malang.

Nur, G. M., \& Rini, R. (2013). S. Gaya belajar; Yogyakarta: Pustaka Pelajar.

Romli, M. (2012). Strategi membangun metakognisi siswa SMA dalam pemecahan masalah matematika; Jurnal Jurusan Pendidikan Matematika FKIP Universitas Madura.

Ruseffendi, E. T. (2006). Pengantar kepada membantu guru mengembangkan kompetensinya dalam pengajaran matematika untuk meningkatkan CBSA; Bandung: Tarsito.

Santrock, J. W. (2007). Psikologi pendidikan (Edisi kedua); Jakarta: Kencana.

Santrock, J. W. (2014). Psikologi pendidikan (Edisi 5-Buku 1); Jakarta: Salemba Empat. 